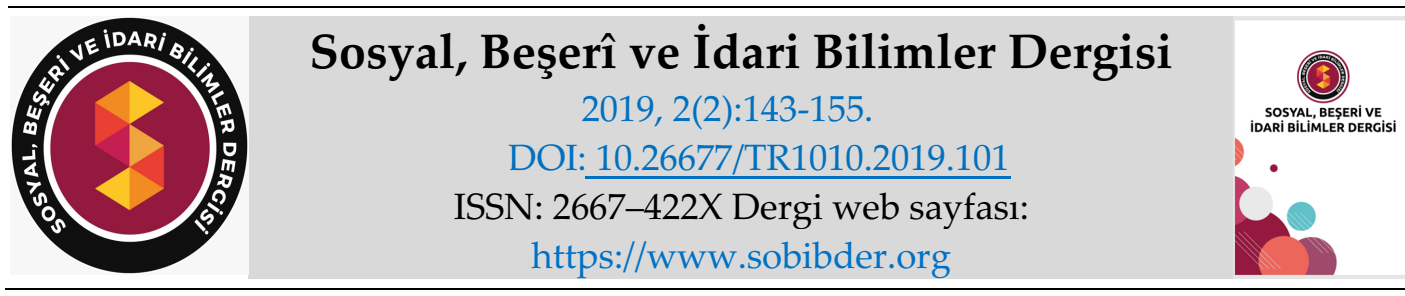

\title{
ARAȘTIRMA MAKALESI
}

\section{Bir Kamu Hastanesinde Süreç Yönetim Sistemi Uygulaması Modeli}

Öğr. Gör. Op. Dr. R. Nurullah SOYHAN, Karabük Üniversitesi Tıp Fakültesi, Karabük, e-posta: nurullahsoyhan@karabuk.edu.tr

ORCID: https://orcid.org/0000-0003-1577-1804

Fatma ÖZCAN KERIM, Karabük Üniversitesi Eğitim ve Araştırma Hastanesi, Karabük, e-posta: fatmaozcankerim@gmail.com

ORCID: https://orcid.org/0000-0001-9906-5741

Dr. Hatice Kübra SOYHAN, Pratisyen Hekim, e-posta: dr.hkubrasoyhan@hotmail.com ORCID: https://orcid.org/0000-0002-5948-1887

Öz

Her işletme veya kurumun ürün veya hizmet üretebilmek için belirlenmiş süreçlere ve bu süreçlerin yönetilmesine ihtiyacı vardır. Süreç yönetimi insan unsurundan bağımsız olamaz ve insan süreçleri, ölçme değerlendirme ve izleme yaparak değiştirmediği ve geliştirmediği sürece sonuç alınamaz. İşletmeler kendileri ve paydaşları için en uygun değeri sağlamak amacı ile süreçlerini tasarlamak ve yönetmek zorundadır. Bu çalışmada Karabük Devlet Hastanesi tüm ana, alt ve detay süreçlerinde, süreç performans ve hedeflerinin sistematik bir şekilde ölçme, izleme ve iyileştirmelerinin sağlanması, tüm çalışanların süreç yönetimine dahil edilerek çalışan motivasyonu ve aidiyet duygusunun artırılması, iç ve dış müşteri beklentilerinin hızlı, kaliteli ve uygun maliyetle karşılanabilmesi, tüm süreçlerin uyum içinde çalışması, bölümler arası bilgi akışının verimli hale getirilmesi ve süreç tekrarlarının azaltılması amaçlanmıştır. Süreç yönetiminin kurumda uygulanmasıyla sürecin işleyişi şeffaf hale gelmiş, süreç performansları netleşmiş, çalışanın sürecin yönetimine dahil edilmesiyle çalışan motivasyonunda artış gözlenmiş ve bu durum hasta memnuniyetine de yansımış, "her süreç bir işletmedir" mantığı yaygınlık kazanmıs, kurumun ana amaç ve hedefleri desteklenmiştir.

Anahtar Kelimeler: Süreç, Süreç Yönetimi, EFQM (Avrupa Kalite Yönetimi Vakfı).

Makale Gönderme Tarihi: 01.03.2019

Makale Kabul Tarihi: 15.04.2019

\section{Önerilen Atıf:}

Soyhan, R. N., Özcan Kerim, F. ve Soyhan, H. K. (2019). Bir Kamu Hastanesinde Süreç Yönetim Sistemi Uygulaması Modeli, Sosyal, Beşeri ve İdari Bilimler Dergisi, 2(2):143-155.

(c) 2019 Sosyal, Beşerî ve İdari Bilimler Dergisi. 


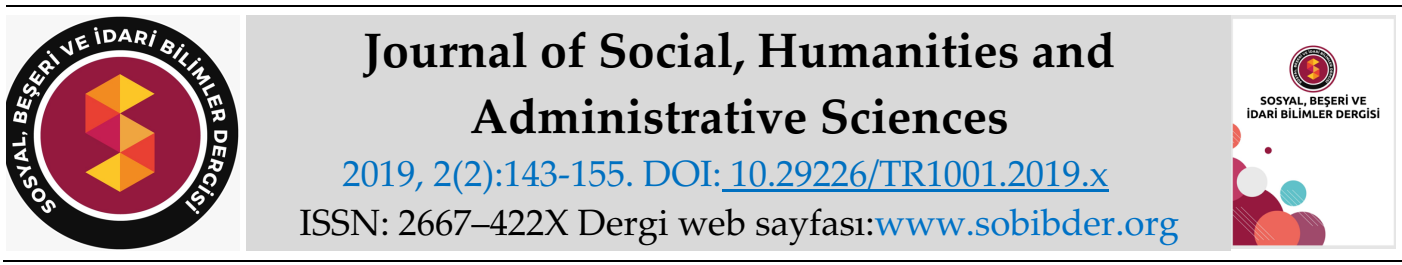

\title{
$\underline{\text { RESEARCH PAPER }}$
}

\section{A Model Study of Process Management in A Public Hospital}

Op. Dr. R. Nurullah SOYHAN, Karabük University Medical School, Karabük, e-mail: nurullahsoyhan@karabuk.edu.tr

ORCID: https://orcid.org/0000-0003-1577-1804

Fatma ÖZCAN KERIM, Karabük University, Training and Research Hospital, Karabük, e-mail: fatmaozcankerim@gmail.com

ORCID: https://orcid.org/0000-0001-9906-5741

Dr. Hatice Kübra SOYHAN, General Practitioner, e-mail: dr.hkubrasoyhan@hotmail.com ORCID: https://orcid.org/0000-0002-5948-1887

\begin{abstract}
Each business or company needs determined processes and process management to produce products or services. Process management cannot be independent of the human factor and cannot be achieved unless human processes are improved through certain alterations via monitoring, tracking and assessment. Businesses should design and manage their processes in order to provide the most appropriate value for themselves and their stakeholders. This study aims at ensuring the measurement, monitoring and improvement of process performance and objectives systematically, to increase the employees' motivation and sense of belonging by incorporating all employees into the process management. This will lead to providing a prompt and a qualified response with relevant cost to domestic and foreign customers' expectations, to ensure that all processes work in harmony, to make productive the interdepartmental information flow as well as reducing the process repetitions. With the implementation of the process management in the business, the course of proceeding has become transparent, the process performance has been clarified and in addition, the employee's motivation increased due to the exposure of the employee to the process management system, which led to an increased level of patient satisfaction. The logic of "every process is a business" gained a wide currency when the main goals and objectives of the institution have been supported.
\end{abstract}

Keywords: Process, Process Management, EFQM (European Quality Management Foundation).

Received: 01.03.2019

Accepted: 15.04.2019

\section{Suggested Citation:}

Soyhan, R. N., Özcan Kerim, F. and Soyhan, H. K. (2019). A Model Study of Process Management in a Public Hospital, Journal of Social, Humanities and Administrative Sciences, 2(2):143-155.

(c) 2019 Sosyal, Beşerî ve İdari Bilimler Dergisi. 


\section{Gíriş}

Her işletme veya kurumun ürün veya hizmet üretebilmek için belirlenmiş süreçlere ve bu süreçlerin yönetilmesine ihtiyacı vardır. Süreç yönetimi insan unsurundan bağımsız olamaz ve insan süreçleri, ölçme değerlendirme ve izleme yaparak değiştirmediği ve geliştirmediği sürece sonuç alınamaz. İşletmeler kendileri ve paydaşları için en uygun değeri sağlamak amacı ile süreçlerini tasarlamak ve yönetmek zorundadır. Tasarlanan süreçlerin işletmenin kılavuzu görevini kusursuz üstlenmesi beklenir. Bu bağlamda her süreç kendi girdileri, uygulamaları ve çıktıları ile ayrı birer yönetim olmakla birlikte bağlı oldukları üst ve alt süreçlerle bir bütündür unsurunu içerecek şekilde tasarlanmalı ve sahiplendirilmelidir. Süreç sahipleri sürecin insan kaynağı unsurudur. İnsan kaynağı ile birlikte tüm kaynakların en verimli ve etkili şekilde kullanılabilmesi sonuçların ölçülüp izlenebilmesi için süreç ve süreç yönetimi önem arz etmektedir.

Bu çalışmada Karabük Devlet Hastanesi tüm ana, alt ve detay süreçlerinde, süreç performans ve hedeflerinin sistematik bir şekilde ölçme, izleme ve iyileştirmelerinin sağlanması, tüm çalışanların süreç yönetimine dahil edilerek çalışan motivasyonu ve aidiyet duygusunun artırılması, iç ve dış müşteri beklentilerinin hızlı, kaliteli ve uygun maliyetle karşılanabilmesi, tüm süreçlerin uyum içinde çalışması, bölümler arası bilgi akışının verimli hale getirilmesi ve süreç tekrarlarının azaltılması amaçlanmıştır.

Çalışmada; Karabük Devlet Hastanesi bu amaçlar doğrultusunda süreçlerini sahiplendirmiş, sorumlularını (süreç lideri) belirlemiş, süreç çalışanlarının ve yönetiminde içinde bulunduğu süreç yönetim ekiplerini kurmuş, kurumun amaç ve hedeflerini destekleyecek şekilde ölçülebilir ve izlenebilir süreç performans parametrelerini belirleyerek, süreç yönetimini oluşturmuştur.

Süreç yönetiminin kurumda uygulanmasıyla sürecin işleyişi şeffaf hale gelmiş, süreç performansları netleşmiş, çalışanın sürecin yönetimine dahil edilmesiyle çalışan motivasyonunda artış gözlenmiş ve bu durum hasta memnuniyetine de yansımış, "her süreç bir işletmedir" mantığı yaygınlık kazanmış, kurumun ana amaç ve hedefleri desteklenmiştir.

\section{SÜREÇ NEDİR?}

Süreç (proses), her birimin uyguladığı işe girdi olan ürün veya hizmeti işleyerek değerini artırdığ1 çıktılara dönüştürdügü faaliyetler bütünüdür. Süreç ile ilgili ilk tanım "American Heritage" sözlüğünde 1978 yılında yapılmıştır. Bu sözlükte süreç "bir son veya bir sonuç meydana getiren bir dizi eylem, değişiklik veya işlev" şeklinde tanımlanmıştır. Bu tanım sistematik iyileştirme ve yeniden tasarlama amaçlarına yönlendirme yapmadığı için bugünkü süreç bakış açısı için yeterli değildir. JURAN (1988) süreci "bir amacın başarılmasına yönlendirilmiş bir dizi sistematik eylem" şeklinde tanımlayarak, sürecin hedeflenen çıtılara ulaşmasını sağlayıcı faaliyetlerden oluştuğunu ifade etmiştir (https://docplayer.biz.tr). İnsan gücü, makina, malzeme, teknoloji gibi girdileri daha değerli çıktı haline dönüştüren, yani katma değer yaratan faaliyet veya faaliyetler dizisidir (danışmend.com).

Süreç, TSE Kalite yönetim sistemi standartlarında ISO 9901-2000 (2001:2) girdileri çıtı haline getiren birbirleriyle etkili ve iletişimli faaliyetler takımı olarak tanımlanmıştır. Ayanoğlu ve Turan (2003: 195)'a göre genişletilmiş tanımı ile süreçler:

- Belirli bir çıktı (hizmet, ürün) elde etmek için birbirleriyle etkileşimde olan insan malzeme yöntem ekipman ve çevrenin toplamıdır.

- Girdileri olan, bunlara müşterileri için değer ekleyen ve çıtı üreten faaliyetler dizinidir. 
- İşletme girdilerini işletme çıtılarına dönüştüren faaliyetler bütünüdür.

- Süreçler 3 temel faaliyet kompozisyonudur ki bunlar müşteriler için değer yaratan önem taşıyan faaliyetler, birimler arası iş akışını sağlayan faaliyetler ve kontrol faaliyetlerinin bileşimidir.

- Yalın hali ile süreçler bir işletmenin müşterileri için ne yaptığıdır.

- Bir organizasyonel süreç, başı ve sonu olan bir iş demektir. Bu işi yapmak için gerekli alt ve detay işlerin oluşumudur.

- İşletmenin ürün/ hizmetini oluşturan mantıksal iş toplamıdır.

- Süreçler birbirini izleyen durum değişikliklerinin analizinden doğarlar.

\section{Sürecin Temel Özellikleri Nedir?}

Bir süreç tanımlanabilir, ölçülebilir, yinelenebilir, kontrol edilebilir, tutarlı ve paydaşları için katma değer sağlayabilir (dönüşüm) olmalıdır. Söz konusu bu temel özellikleri detaylandırmak gerekirse;

Tanımlana bilirlik: Sürecin tüm unsurları + müşteri istek ve beklentileri + performans hedefi ifade etmektedir.

Ölçülebilir: Performans ölçümleri ile izlenebilme ölçülemeyen bir hizmeti geliştirmek ve yönetmek zordur.

Yinelene bilirlik: Değerlendirme işlemi ana süreçte sürekli tekrarlanabilir. İşlem sayısı yinelenebilir olduğunda ölçme ve değerlendirme daha kolay yapıla bilinir.

Kontrol edilebilirlik: Süreç sonunda değil süreç boyunca kontrol hataları kaynağında önlemek sorunları büyümeden çözümlemek işlerin kontrolünü yapmak olmalıdır.

Tutarlılık: Süreçte tutarlılık ve az sayıda değişiklik süreçlerin istatistiksel anlamda kontrol altında tutulması sapmaların en aza indirilmesi standartlaşma sağlar.

Dönüşüm: Girdileri değer kazanmış çıktılara dönüştürebilmek fiziksel, konumsal, değersel, bilgisel dönüşümü ifade etmektedir (Özay, 2003:19).

\section{Süreç Sınıflandırması Nasıl Olmalıdır?}

Süreç sınıflandırma her kurum ve kuruluş için önem düzeylerine göre değişiklik gösterebilir. Karabük Devlet Hastanesi kendi süreçlerini aşağıdaki gibi sınıflandırmış ve detaylandırmıştır. Turan (1998: 89-90) süreçleri ana hatları ile aşağıdaki şekilde sınıflandırmıştır.

Temel Süreçler: İşletmenin ana hedefini oluşturan doğrudan diş müşteri talebi ile şekillenip diş müşteriye çıktı veren süreçlerdir. Karabük Devlet Hastanesi için temel süreçler tıbbi süreçler olarak verilmiştir.

Yönetim Süreçleri: Ortak hedefler belirleyerek her bir sürecin izlenebilir ölçülebilir ve raporlanabilir halde yürümesini sağlayan süreçlerdir. Bizim için yönetim süreçleri idari ve yönetsel süreçler olarak isimlendirilmiştir.

Destek Süreçleri: Tüm kaynakların ortak amaç çatısı altında en verimli şekilde kullanılmasını sağlayan süreçlerdir. Karabük Devlet Hastanesi için mali süreçler olarak verilmiştir.

Süreç yönetimi, tüm sistem süreçleri için standart sistem geliştirme araçlarının, tekniklerinin ve teknolojilerinin planlanması, seçimi ve istikrarlı bir şekilde uygulanmasını ifade etmektedir (Tütüncü vd., 2004: 2). 


\section{Üst Yönetimin Süreç Yönetimindeki Sorumlulukları}

- Süreç sahiplerini atar.

- Kalıcı süreç ekiplerini belirler.

- Süreç ekibinin tavsiyelerini alır.

- Süreç ölçümlerini izler ve ekibe geri bildirim verir.

- Süreç sahiplerinden gelen problemleri çözüme kavuşturur.

- Süreçler arası ilişkileri düzenler ve çelişkileri çözümler.

- Süreç performansını gözden geçirir.

- Süreç iyileştirmelerini tanır/ödüllendirir.

- Stratejik ve işlevsel değiş̧iklikleri tartışırken akış diyagramlarını kullanır.

- Bölümler arası kopuklukları giderir.

\section{Süreç Ekibinin Süreç Yönetimindeki Sorumlulukları}

- Süreç iyileştirmesini analiz eder.

- Değişiklikler yapar ve/veya önerir.

- Bölümler arası konuları süreç sahibine iletir.

- Süreç iyileştirmelerini uygular.

- Süreç performansını izler ve problemleri giderir.

- Ölümlerdeki gelişmeleri inceler ve geri bildirim sistemlerini değerlendirir ve önerilerde bulunur.

\section{Süreç Hiyerarşisi Nedir?}

Süreç hiyerarşisi süreçlerin kapsamlarına göre kademeli olarak yapılandırılmalarıdır. Hiyerarşi, kapsamı en büyük olan süreçten başlayarak detaylara inilecek şekilde yapılandırılır. Ayanoğlu ve Turan (2003:196-197) Bu yapılandırma;

Ana Süreçler: İş sonuçları üzerinde direkt etkisi olan ve stratejik öneme sahip üst seviyede süreçlerdir.

Alt Süreçler: Ana süreçleri oluşturan ve birbirleri ile etkileşimde olan süreçlerdir.

Detay Süreçler: Alt süreçleri oluşturan ve iki veya daha fazla fonksiyonu ilgilendiren faaliyetlerdir. Karabük Devlet Hastanesi hiyerarşisi aşağıdaki gibidir.

\section{A. TIBBİ (OPERASYONEL) ANA SÜREÇLER}

1.Klinik Hizmetleri Alt Süreçleri

a. Dahili Klinikler Alt Süreçleri

-Cildiye, İntaniye Kliniği Detay Süreci

-Dahiliye, Kardiyoloji Kliniği Detay Süreci

-FTR Detay süreci

-Nöroloji Kliniği Detay Süreci

-Göğüs Hastalıkları Kliniği Detay Süreci 
-Psikiyatri Kliniği Detay Süreci

b. Cerrahi Klinik Alt Süreçleri

-Genel Cer., Göğüs Cer., Kalp Damar Cer. Kliniği Detay Süreci

-Ortopedi Göz Kliniği Detay Süreci

-KBB Üroloji Kliniği Detay Süreci

c. Acil Klinik Alt Süreci

d. Hemodiyaliz Klinik Alt Süreci

e. Ameliyathane Alt Süreci

f. Yoğun Bakım Alt Süreçleri

-Cerrahi Yoğun Bakım Detay Süreci

-Koroner Yoğun Bakım Detay Süreci

-Göğüs Hastalıkları Yoğun Bak. Detay Süreci

2. Poliklinik Hizmetleri Alt Süreçleri

a. Dahili Poliklinik Alt Süreçleri

-Cildiye Polikliniği Detay Süreci

-Dahiliye Polikliniği Detay Süreci

-Fizik Tedavi Polikliniği Detay Süreci

-Gögüs Hastalıkları Polikliniği detay Süreci

-İntaniye Polikliniği Detay Süreci

-Kardiyoloji Polikliniği Detay Süreci

-Psikiyatri Polikliniği Detay Süreci

-Nöroloji Polikliniği Detay Süreci

b. Cerrahi Poliklinik Alt Süreçleri

-Beyin Cerrahi Polikliniği Detay Süreci

-Genel Cerrahi Polikliniği Detay Süreci

-Göğüs Cerrahi Polikliniği Detay Süreci

-Göz Polikliniği Detay Süreci

-KBB Polikliniği Detay Süreci

-Ortopedi Polikliniği Detay Süreci

-Plastik Cerrahi Polikliniği Detay Süreci

-Üroloji Polikliniği Detay Süreci

-Kalp Damar Cerrahi Detay Süreci

3.Tetkik Hizmetleri Alt Süreçleri

a. Laboratuvarlar Alt Süreci

-Biyokimya Laboratuvarı Detay Süreci

-Mikrobiyoloji Laboratuvarı Detay Süreci

-Patoloji Laboratuvarı Detay Süreci

b. Tetkik Birimleri Alt Süreci

-Uyku Merkezi Detay Süreci

-İsitme ve Denge Merkezi Detay Süreci

- Radyoloji Hizmetleri Detay Süreci

-Endoskopi Detay Süreci

4.Yardımcı Sağlık Hizmetleri Alt Süreçleri

- Eczane Detay Süreci

-Anestezi Hizmetleri Detay Süreci

- Enfeksiyonların Önlenmesi ve Kontrolü Detay Süreci

B. İDARI VE YÖNETSEL ANA SÜREÇLER

1. Hizmet Alımları Alt Süreçleri

-Güvenlik Hizmetleri Detay Süreci 
-Temizlik Hizmetleri Detay Süreci

-Yemekhane Hizmetleri Detay Süreci

2. Teknik Servis Alt Süreci

-Biyomedikal ve Kalibrasyon Hizmetleri Detay Süreci

-Atölye Hizmetleri Detay Süreci

-Bilgi İşlem Hizmetleri Detay Süreci

3. Kalite Yönetim Sistemleri Alt Süreci

4. Hasta Hakları, Halkla İlişkiler Alt Süreci

5. Arşiv Hizmetleri Alt Süreci

C. MALİ SÜREÇLER

1. Tahakkuk Hizmetleri Alt Süreci

-Gelir Tahakkuku Detay Süreci

-Gider Tahakkuku Detay Süreci

-Mutemetlik Hizmetleri Detay Süreci

2. Satın Alma Alt Süreci

-Yaklaşık Bedel Tespit Kurulu Detay Süreci

-Teknik Şartname Hazırlama Detay Süreci

-İhale Detay Süreci

\section{YÖNTEM VE BULGULAR}

Karabük Devlet Hastanesi, süreçlerini TSE Kalite Yönetim Sistemi (ISO 9001:2008) çerçevesinde EFQM mükemmellik modeli 5. kriteri (Süreçler, Ürünler ve Hizmetler) nin 5 boyutunu ve 27 alt boyutunu KalDer (2003:20-21) karşılayacak yapıda oluşturmuştur. Çalışmaya genel süreç yönetim sistemi lideri belirlenerek süreç yönetim sistemi ekibi kurulmuş ve bu ekip kurumun organizasyon şemasında doğrudan üst yönetime bağlı olarak faaliyetlerini yürütmüştür. Süreçler üç ana süreç olan tıbbi, mali ve yönetsel ve idari süreçler 11 alt ve 26 detay süreç olarak sınıflandırılmıştır. Ana süreçler sahiplendirilmiş, alt ve detay süreçlerin sorumluları (süreç lideri) belirlenmiş, süreç çalışanlarının ve yönetiminde içinde bulunduğu süreç yönetim ekiplerini kurmuş, kurumun amaç ve hedeflerini destekleyecek şekilde ölçülebilir ve izlenebilir süreç performans parametrelerini belirleyerek, süreç yönetimini oluşturmuştur. Her alt süreç belirlenmiş performans kriterleri ile ve algılama ölçümleri ile değerlendirilmektedir.

2009 yılında ISO 9001:2008 belgelendirme çalışmalarında tüm süreçlerin çalışanlarından SWOT analizleri alınmış ve süreçlerin dokümantasyonu SWOT analizlerinden yararlanarak çalışanlar ile hazırlanmıştır. Süreç dokümanları hazırlanırken süreç öğelerinin (tedarikçi, girdi, çıktı, müşteri), sorumlulukların ve süreç detayının doğru tanımlanması amaçlanmıştır. Dokümantasyonun süreçlerimizin işlemesinde, gözden geçirilmesinde ve iyileştirilmesinde kılavuz görevi görmesi ve çalışanların uyumuna destek olması sağlanmıştır. Her süreç doğrudan başhekime bağlı olan ana sürecin altında sınıflandırılarak yönetim sisteminin birer öğesidir. Böylece süreçler arası iletişimin de kesintisiz yürütülmesi sağlanmıştır. 
Tablo 1: Süreç Yönetim Sistemi

\begin{tabular}{|c|c|c|}
\hline Aşama & Katılanlar & Ortam \\
\hline Süreç Yönetimi eğitimi alınması & $\begin{array}{l}\text { Kalite Ekibi, Süreç çalışanları, yönetim } \\
\text { sistemleri liderleri, üst yönetim }\end{array}$ & $\begin{array}{l}\text { Eğitim } \\
\text { salonu }\end{array}$ \\
\hline Süreçlerin belirlenmesi & Kalite Ekibi-Süreç yönetim sistemi ekibi & Kalite Birimi \\
\hline $\begin{array}{l}\text { Süreç sorumlularının (liderleri) } \\
\text { belirlenmesi }\end{array}$ & $\begin{array}{l}\text { Süreç yönetim sistemi ekibi, Kalite Ekibi, } \\
\text { Üst Yönetim }\end{array}$ & Kalite Birimi \\
\hline Süreç kartlarının hazırlanması & $\begin{array}{l}\text { Kalite ekibi, Süreç Yönetim sistemi Ekibi, } \\
\text { Süreç Sorumluları }\end{array}$ & $\begin{array}{l}\text { Süreç } \\
\text { Toplantıları }\end{array}$ \\
\hline $\begin{array}{l}\text { Performans Parametrelerinin } \\
\text { belirlenmesi }\end{array}$ & $\begin{array}{l}\text { Kalite Ekibi, Süreç Yönetim sistemi Ekibi } \\
\text { ve İlgili Süreç Çalsşanları }\end{array}$ & Kalite Birimi \\
\hline Kilit Süreçlerin belirlenmesi & $\begin{array}{l}\text { Kalite Ekibi ve Üst Yönetim, Süreç } \\
\text { Yönetim sistemi Ekibi }\end{array}$ & Kalite Birimi \\
\hline $\begin{array}{l}\text { Süreçlerin mevcut durumlarının } \\
\text { tespiti }\end{array}$ & Süreç Yönetim Ekibi & $\begin{array}{l}\text { Süreç } \\
\text { Toplantıları }\end{array}$ \\
\hline $\begin{array}{l}\text { Performans Parametrelerine } \\
\text { göre süreçlerin hedeflerinin } \\
\text { belirlenmesi }\end{array}$ & Süreç Yönetim Ekibi & $\begin{array}{l}\text { Süreç } \\
\text { Toplantıları }\end{array}$ \\
\hline $\begin{array}{l}\text { Hedeflerin İzlenmesi ve } \\
\text { Ölçülmesi }\end{array}$ & $\begin{array}{l}\text { Süreç lideri ve Çalışanları Süreç Yönetim } \\
\text { Ekibi }\end{array}$ & $\begin{array}{l}\text { Süreç } \\
\text { Toplantıları }\end{array}$ \\
\hline $\begin{array}{l}\text { Elde edilen öğrenmelerin } \\
\text { paylaşılması ve iyileştirmelerde } \\
\text { kullanılması }\end{array}$ & $\begin{array}{l}\text { Süreç lideri ve Çalışanları Süreç Yönetim } \\
\text { Ekibi }\end{array}$ & $\begin{array}{l}\text { Süreç } \\
\text { Toplantıları }\end{array}$ \\
\hline Süreçlerin İyileştirilmesi & $\begin{array}{l}\text { Süreç lideri ve Çalışanları Süreç Yönetim } \\
\text { Ekibi }\end{array}$ & $\begin{array}{l}\text { Süreç } \\
\text { Toplantıları }\end{array}$ \\
\hline
\end{tabular}


Tablo: 2 Süreçler Arası İletişim

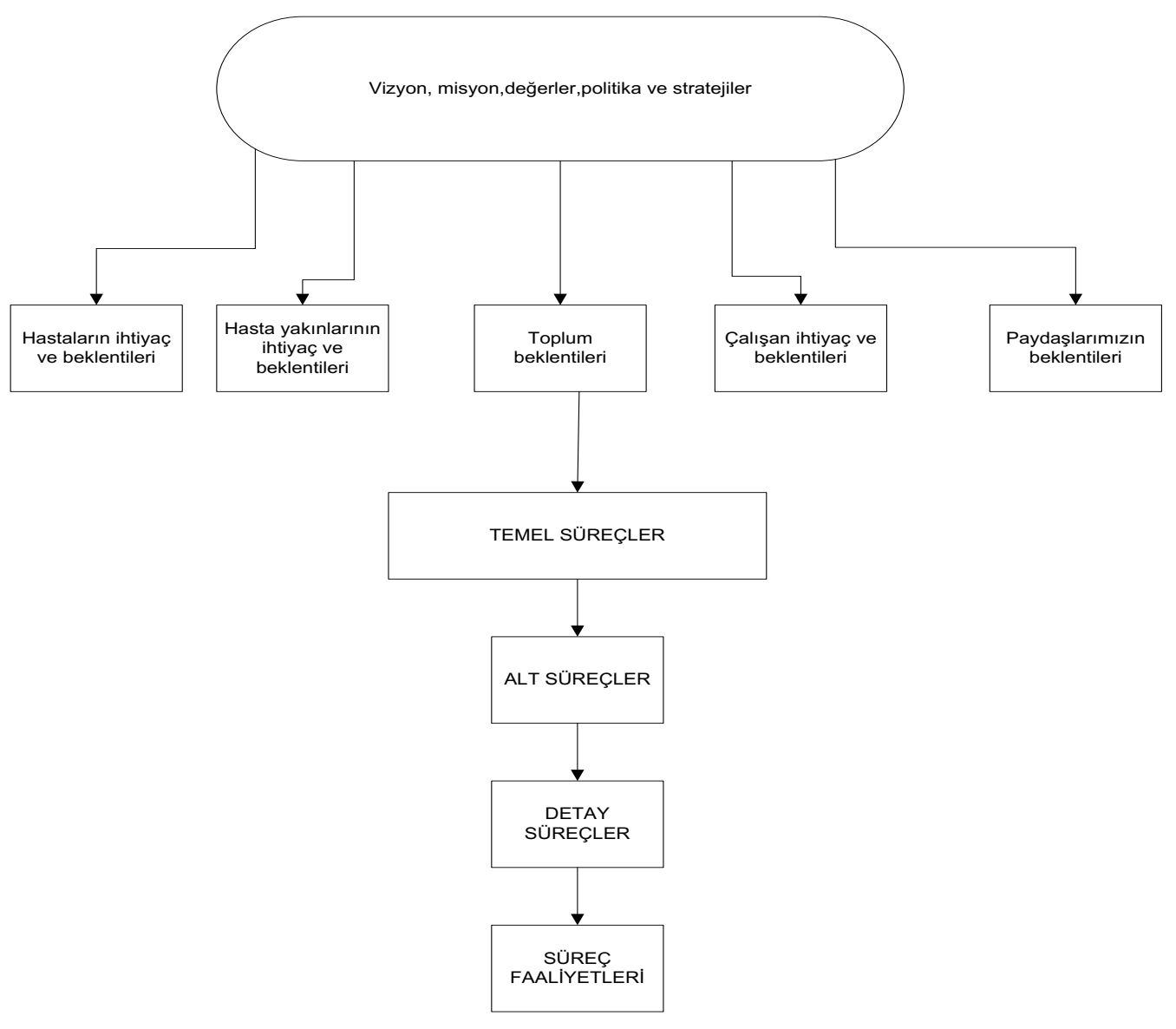

\section{SÜREÇ TASARLAMA YAKLAŞIMI}

Süreçlerin tüm aşamalarında, odaklanacak noktaları ve ilgili tarafları netleştirmek amacı ile aynı amaca hizmet eden süreçler aynı grup altında toplanarak 3 ana süreç oluşturulmuştur. Bu üç ana süreçten kritik başarı faktörlerimizi doğrudan etkileyen tıbbi süreçler kilit süreçlerimiz olarak belirlenmiştir. Süreçlerin yapılandırılması aşamasında TSE ve danışman firmadan eğitim ve destek alınmıştır. Dokümantasyonda TSE ISO 90012008 dokümantasyon hiyerarşisi model alınmış prosedürler, akış şemaları, talimatlar, olarak hazırlanmıştır. Her süreç için prosedür, proses kartları, iş akışları ve görev tanımları oluşturulmuş, birimlere dağıtılmış ve intranetten de yayınlanmıştır. Dış kaynak kullanılarak işleyen süreçler 3 ana süreç altında Yönetsel ve idari süreçlerimizin içerisinde hizmet alımları süreci olarak ele alınmakla birlikte, kurum itibarı yönetim sistemi, iş birlikleri ve tedarik zinciri yönetim sistemi gibi yönetim sistemlerimizle de dış kaynaklı süreçlerimizin kurum kültürüne ve işleyişine entegre olmalarını sağlamaktadır. Her süreç kendi girdileri, uygulamaları ve çıktıları ile ayrı birer yönetim olmakla birlikte bağlı oldukları üst ve alt süreçlerle bir bütündür. 3 aylık aralıklarla yapılan süreç toplantılarında çıkan kararlar doğrultusunda gerekli değişiklikler ve iyileştirmeler yapılır. Bu değişiklikler ilgili tüm birimlere iç tamimle, intranetle ve bültenle duyurulur. Yine bu toplantılarda süreçler ve süreçler arası işleyişten kaynaklanan bir sorun var ise ilgili süreç sorumlusunun da katılımıyla problemler değerlendirilip, beyin fırtınası yöntemiyle geliştirilen çözümler uygulamaya alınır. 
Aşılamayan sorunlar da ana süreç sahiplerinin düzenlediği toplantılarda aynı yöntemle çözümlenir.

Tablo 3: Ana ve Alt süreçleri

\begin{tabular}{|c|c|c|}
\hline ANA SÜREÇLER & ALT SÜREÇLER & SÜREÇ SAHİBİ \\
\hline T1bbi süreçler & $\begin{array}{ll}\text { - } & \text { Poliklinik Hizmetleri } \\
\text { - } & \text { Klinik Hizmetleri } \\
\text { - } & \text { Tetkik ve Tanı Hizmetleri } \\
\text { - } & \text { Yardımcı Sağlık Hizmetleri }\end{array}$ & Başhekim Yardımcısı \\
\hline $\begin{array}{l}\text { Yönetsel ve idari } \\
\text { süreçler }\end{array}$ & $\begin{array}{ll}\text { - } & \text { Hizmet alımları süreci } \\
\text { - } & \text { Teknik servis süreci } \\
\text { - } & \text { Kalite yönetimi sistemleri süreci } \\
\text { - } & \text { Halkla ilişkiler süreci } \\
\text { - } & \text { Arşiv hizmetleri süreci }\end{array}$ & Başhekim Yardımcısı \\
\hline Mali süreçler & $\begin{array}{l}\text { - Tahakkuk süreci } \\
\text { - Satın alma süreci }\end{array}$ & Başhekim Yardımcısı \\
\hline
\end{tabular}

Süreç yönetiminde, süreç izlemeleri tüm detay süreçlerde aynı uygulanmakla birlikte, Tablo 4'te Dahili klinikler alt süreci altında bulunan Gögüs hastalıkları detay süreci verilmiştir. Her süreç kendi içerisinde süreç yönetim ekibinin 3 aylık periyotlarda yapmış olduğu süreç toplantılarında süreç izlem formu ile verilerini takip edebilmektedir. Uygulama sürecin işleyişini şeffaf hale getirmiştir. Süreç toplantılarında veriler gözden geçirilmekte, hedefe ulaşılamayan veya pozitif artış görülmeyen stratejilerde iyileştirmeye açık alanlar belirlenmekte ve iyileştirmeler yapılmaktadır. Toplantılarda süreç çalışanlarının ve yönetimin birlikte olması iyileştirme alanlarının belirlenmesini ve iyileştirmelerin yapılmasını kolaylaştırmaktadır. Hedefe ulaşılan parametreler, yine süreç toplantılarında gözden geçirilmekte uygun bulunanlar hedeften çıkarılarak stratejiyi destekleyecek başka parametre belirlenmektedir. Hastanemiz Göğüs hastalıkları servisinde "yatak işgal oranını artırmak" "48 saat içinde tekrar yatışı önlemek" parametrelerinde olduğu gibi hedeften çıkarılması uygun olmayan parametreler hedefe ulaşılsa bile hedefte sabit tutulması için izlenmeye devam edilmektedir. Gögüs hastalıkları servisinde acil yatışlar göz önünde bulundurularak "yatak işgal oranını artırmak" hedefi \%100'e çıkarılmamıştır. Stratejiler hastanenin amaçları doğrultusunda oluşturulmuş olup hedeflere yaklaşıldığı ve böylelikle de hastanenin amaçlarını desteklediği görülmektedir. 
Tablo 4: Süreç İzlem Formu

\begin{tabular}{|c|c|c|c|c|c|c|}
\hline & & $\begin{array}{r}\text { SAĞ } \\
\text { KARABÜK } \\
\text { DAHİLİ KLİNİKLE } \\
\text { (Göğüs Hastalı }\end{array}$ & $\begin{array}{r}\text { T.C } \\
\text { IK BAI } \\
\text { DEVLE } \\
\text { ALT S } \\
\text { sları KI } \\
\end{array}$ & $\begin{array}{l}\text { NLIĞI } \\
\text { HASTA } \\
\text { RECI I } \\
\text { iği Det }\end{array}$ & $\begin{array}{l}\text { ESİ } \\
\text { EM FORMU } \\
\text { Süreci) }\end{array}$ & \\
\hline 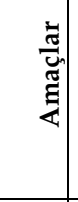 & Stratejiler & Süreç Parametreleri & 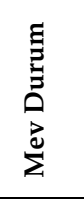 & 岕 & Süreç Hedefleri & Periyot \\
\hline & & $\begin{array}{l}\text { Yatak işgal oranını } \\
\text { artırmak }\end{array}$ & $\% 98$ & $\% 98$ & $\begin{array}{l}\text { Yatak işgal oranını hedefte } \\
\text { sabit tutmak }\end{array}$ & 3 Aylik \\
\hline $\begin{array}{l}\text { है } \\
\text { छ }\end{array}$ & Etkin & $\begin{array}{l}\text { Yatak devir hızını } \\
\text { artırmak }\end{array}$ & $\% 4$ & $\% 5$ & $\begin{array}{l}\text { Hasta yatış sürelerini } \\
\text { kısaltmak }\end{array}$ & 3 Aylik \\
\hline 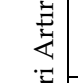 & & $\begin{array}{l}\text { Yatan hasta sayısını } \\
\text { artırmak }\end{array}$ & 121 & 150 & $\begin{array}{l}\text { Gereksiz yere yatışları } \\
\text { önlemek }\end{array}$ & 3 Aylik \\
\hline 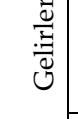 & $\begin{array}{l}\text { Veri giriş } \\
\text { hatalarını en } \\
\text { aza indirmek }\end{array}$ & $\begin{array}{l}\text { Tahakkuk miktarını } \\
\text { artırmak }\end{array}$ & $\begin{array}{l}68.45 \\
8\end{array}$ & $\begin{array}{l}75.00 \\
0\end{array}$ & $\begin{array}{l}\text { Hasta dosyalarını eksiksiz } \\
\text { teslim etmek }\end{array}$ & 3 Aylik \\
\hline & $\begin{array}{l}\text { Sevkleri } \\
\text { önlemek } \\
\end{array}$ & Sevk sayısını azaltmak & $\% 4$ & $\% 1$ & $\begin{array}{l}\text { Gereksiz yere hasta sevk } \\
\text { etmemek }\end{array}$ & 3 Aylik \\
\hline & $\begin{array}{l}\text { Yatış } \\
\text { tekrarını } \\
\text { önlemek }\end{array}$ & $\begin{array}{l}48 \text { saat içinde tekrar yatışı } \\
\text { önlemek }\end{array}$ & $\% 0$ & $\% 0$ & $\begin{array}{l}48 \text { saat içerisinde tekrar yatış } \\
\text { oranını hedefte sabit tutmak }\end{array}$ & 3 Aylik \\
\hline है & $\begin{array}{l}\text { İlaç ve sarf } \\
\text { malzemenin }\end{array}$ & $\begin{array}{l}\text { Tibbi sarf malzeme } \\
\text { giderlerini azaltmak }\end{array}$ & 1.100 & 1.000 & $\begin{array}{l}\text { Sarf malzemeyi etkin } \\
\text { kullanmak }\end{array}$ & 3 Aylik \\
\hline 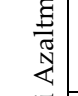 & $\begin{array}{l}\text { etkin } \\
\text { kullanımı }\end{array}$ & $\begin{array}{l}\text { Aylık ilaç giderlerini } \\
\text { azaltmak }\end{array}$ & 3.469 & 3.300 & $\begin{array}{l}\text { Gereksiz antibiyotik } \\
\text { kullanımını önlemek }\end{array}$ & 3 Aylik \\
\hline 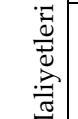 & Hastaların & $\begin{array}{l}15 \text { Günden fazla yatan } \\
\text { hasta sayısını düşürmek }\end{array}$ & $\% 8$ & $\% 5$ & $\begin{array}{l}15 \text { Günden fazla yatan hasta } \\
\text { oranını düşürmek }\end{array}$ & 3 Aylik \\
\hline$\Sigma$ & $\begin{array}{l}\text { hastanede } \\
\text { kalış süresini } \\
\text { kısaltmak }\end{array}$ & $\begin{array}{l}\text { Ortalama yatış süresini } \\
\text { kısaltmak }\end{array}$ & 9gün & 5gün & $\begin{array}{l}\text { Ortalama yatış gün süresini } \\
\text { düşürmek }\end{array}$ & 3 Aylik \\
\hline & & $\begin{array}{l}\text { Nazokomiyal enfeksiyon } \\
\text { oranını düşürmek }\end{array}$ & $\% 5$ & $\% 1$ & $\begin{array}{l}\text { Nazokomiyal enfeksiyon } \\
\text { oranını düşürmek }\end{array}$ & 3 Aylik \\
\hline 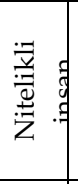 & $\begin{array}{l}\text { Nitelikli } \\
\text { insan gücünü } \\
\text { artırmak }\end{array}$ & $\begin{array}{l}\text { Birim içi eğitim } \\
\text { etkililiğini artırmak }\end{array}$ & $\begin{array}{l}\text { Ortal } \\
\text { ama } \\
60 \\
\text { puan }\end{array}$ & $\begin{array}{l}\text { Ortal } \\
\text { ama } \\
80 \\
\text { puan }\end{array}$ & $\begin{array}{l}\text { Ön test son test sonuçlarını } \\
\text { yükseltmek }\end{array}$ & 3 Aylik \\
\hline 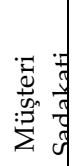 & $\begin{array}{l}\text { Otelcilik } \\
\text { hizmetlerini } \\
\text { iyileştirmek }\end{array}$ & $\begin{array}{l}\text { Hasta memnuniyetini } \\
\text { artırmak }\end{array}$ & $\% 88$ & $\% 95$ & $\begin{array}{l}\text { Hasta memnuniyeti oranını } \\
\text { artırmak }\end{array}$ & 3 Aylik \\
\hline
\end{tabular}




\section{TARTIŞMA VE SONUÇ}

Kurumlarda süreçlerin yönetimi ile hizmet veya malzeme üretimi olsun çıtıların etkili, verimli, kaliteli, beklentileri karşılama düzeyi yüksek ve yalın hale getirilerek, her süreç bir işletmedir mantığı ile işletilmesi, faaliyetlerin tepeden etkili yönetilemeyeceğinin farkındalığı ile çalışanların sürecin yönetimine dahil edilmesi, süreç faaliyetlerinin ölçülebilir ve izlenebilir olmasının sağlanması kamu veya özel tüm kurumlarda son derece önemlilik arz etmektedir.

Karabük Devlet Hastanesi oluşturduğu süreç yönetimi ile aşağıdaki sonuçlara ulaşmıştır.

- Yapılan çalışma sonucunda süreç kavramı keşfedilmiştir.

- İşleyen birimler ayrı birer yönetim olarak kabul edilmiştir.

- Açık olmayan süreç performans hedefleri netleştirilmiştir.

- Kurumun amaç ve hedefleri doğrultusunda süreç hiyerarşisi belirlenmiştir.

- Sahiplendirilen süreçler sadece yönetim ve ürün boyutunda takip edilmekten çıkmış tüm yönleri ile izlenebilir olmuş, sürecin işleyişi şeffaf hale gelmiştir.

- İzlenebilir hale getirilen süreçler kurum hedefleri ile eş güdümlü olması sağlanmış, kurumun ana amaç ve hedefleri desteklenmiştir.

- Her bir çalışan kendi sürecinden haberdar ve sorumlu hale gelmiş, 'her süreç bir işletmedir" mantığı yaygınlık kazanmıştır.

- Çalışanın sürecin yönetimine dahil edilmesiyle çalışan motivasyonunda artış gözlenmiş ve bu durum hasta memnuniyetine de yansımıştır.

- Oluşturulan yöntem ile yeni süreçlerin entegrasyonu hızlanmıştır.

- Sürecin girdileri de göz önüne alınmış ve farkındalık oluşturulmuştur.

- Oluşturulan çıktılar bir sonraki sürecin girdisi olarak teslim edilme bilinci oluşmuştur.

\section{KAYNAKÇA}

Ayanoğlu, M ve Turan, H, (2003). İşletmelerde Süreç Yönetimine Geçiş ve Uygulama Sonuçları, III. Ulusal Üretim Araştırmaları Sempozyumu Bildiriler Kitabı İstanbul Kültür Üniversitesi 1920 Nisan 2003

Demirkol, Ş. (2002). Süreç Tasarımı Değişim Mühendisliği, Modern Yönetim Yaklaşımları, Ed. İ. Dalay-R. Coşkun-R. Altunışık, Beta Yay., İstanbul,

Dinçer, Ö. (1998) Stratejik Yönetim ve Politikası, 5. Baskı, Beta Yay., İstanbul

Eyüboğlu F. (2010). Süreç Yönetimi ve Süreç İyileştirme, İstanbul: Sistem Yayıncılık

http://danismend.com/kategori/altkategori/surec-yonetimine-giris ,erişim Nisan.2019

https://docplayer.biz.tr/111955653-Bir-hizmet-isletmesinde-musteri-memnuniyet-surecinindinamik-bir-analizi-karar-destek-sistemi-uygulamasi.html, erişim Şubat 2018

http://yunus.hacettepe.edu.tr/ umutal/lesson/bby374/05-2014.pdf, Erişim Şubat 2018

KalDer (1999-2003) 20-21. EFQM (Avrupa Kalite Yönetim Vakfı) Mükemmellik Modeli, Kamu ve Sivil Toplum, Türkiye Kalite Derneği KalDer Yayınları İstanbul.

Mark McDonald (2011). İş Süreçlerini İyileştirmek, Optimist Yayınevi. 
Özay, H. E. (2003). Süreçlerle Yönetim Sistemi ve Küçük Orta Ölçekli Bir İşletmede Uygulanması, Dokuz Eylül Üniversitesi İşletme Yüksek Lisans Tezi, İzmir.

Özcan S. (2006). Süreç Yönetimi, Çağdaş Yönetim Araçlarından Seçmeler, Ed. M.Ş. Şimşek - S. Kırgır, Nobel Yay., Ankara.

Peker, Ö. ve Aytürk N., (2002). Yönetim Becerileri, Ankara: Yarg1 Yayınları.

Turan H. (1998) Arçelikte Süreç Yönetimi Üretim Süreci, 7.Ulusal Kalite Kongresi Tebliğler ve Özgeçmişler Kitabı, Cilt 1, İstanbul 11-12 Kasım 1998

TSE (Türk Standartları Enstitüsü) TST ISO 90012000 (2001:2) Kalite Yönetim Sistemi Şartlar

TSE (Türk Standartları Enstitüsü) TST ISO 90012008 (2008 4-13-15) Kalite Yönetim Sistemi Şartlar.

Tütüncü, Ö., İpekgil Doğan, Ö. ve Topoyan, M. (2004). Süreçlerle Yönetim ve Bir Hizmet Organizasyonu Uygulaması, IV. Ulusal Üretim Araştırmaları Sempozyumu. Selçuk Üniversitesi, Konya, 8-10 Ekim 2004. 